\title{
GAYA KEPEMIMPINAN DAN MOTIVASI, PENGARUHNYA TERHADAP KINERJA PEGAWAI
}

\author{
Nurjaya $^{1}$, Afiah Mukhtar ${ }^{2}$, A. Nur Achsanuddin UA ${ }^{3}$ \\ IAIN Parepare ${ }^{1}$, Sekolah Tinggi Ilmu Ekonomi Tri Darma Nusantara ${ }^{2}$, \\ Universitas Muhammadiyah Makassar ${ }^{3}$ \\ nurjaya.gani@gmail.com ${ }^{1}$, afiah.muhtar@gmail.com² ${ }^{2}$,nur.achsanuddin@unismuh.ac.id ${ }^{3}$
}

\begin{abstract}
This research aims to determine the style of leadership and motivation to affect the performance of the employees of Bank BTPN branch in Indonesia. The type of research used is quantitative research. Data collection is done by dividing the questionnaire to 32 respondents Bank BTPN branches This study uses multiple linear regression analysis methods. The results of this study showed that, based on statistical test $T$, the count $T$ value for the leadership style variable 3,233 > T table 1.695 and a significant value of $0.002<$ 0.05 . While the motivation variable $5.637>T$ table 1.695 and a significant value of $0.000<0.05$. So it can be concluded the style of leadership and motivation significantly influence the employee's performance.
\end{abstract}

Keywords: leadership style, motivation, employee performance

\begin{abstract}
Abstrak
Penelitian ini bertujuan untuk mengetahui gaya kepemimpian dan motivasi berpengaruh terhadap kinerja pegawai Bank BTPN Cabang Sungguminasa Kabupaten Gowa. Jenis penelitian yang digunakan adalah penelitian kuantitatif. Pengumpulan data dilakukan dengan membagi kuesioner kepada 32 responden pegawai Bank BTPN Cabang Sungguminasa Kabupaten Gowa. Penelitian ini menggunakan metode analisis regresi linear berganda. Hasil dari penelitian ini menunjukkan bahwa, berdasarkan uji statistik $t$, nilai t hitung untuk variabel gaya kepemimpinan $3.233>\mathrm{t}$ tabel 1,695 dan nilai signifikan 0,002 < 0,05. Sedangkan variabel Motivasi 5,637> t tabel 1,695 dan nilai signifikan $0,000<0,05$. Sehingga dapat disimpulkan gaya kepemimpinan dan motivasi berpengaruh signifikan terhadap kinerja pegawai.
\end{abstract}

Kata Kunci: Gaya Kepemimpinan, Motivasi, Kinerja Pegawai

\section{Pendahuluan}

Manajemen sumber daya manusia adalah suatu proses menangani berbagai masalah pada ruang lingkup karyawan, pegawai, buruh. Manajer dan tenaga kerja lainnya untuk dapat menunjang aktivitas organisasi atau perusahaan demi mencapai tujuan yang telah di tentukan.

Kinerja merupakan hasil kerja yang mampu diperoleh pekerja, sebuah proses manajemen atau suatu organisasi secara keseluruhan, dimana hasil kerja tersebut dapat ditunjukan buktinya secara nyata baik dari segi kualitas maupun kuantitas. Kinerja juga merupakan perilaku nyata yang ditampilkan setiap orang sebagai prestasi kerja yang dihasilkan oleh sesuai dengan perannnya, kinerja karyawan merupakan hal yang sangat penting dalam upaya perusahaan untuk mencapai tujuannya.

Kepemimpinan merupakan proses mempengaruhi dalam menentukan tujuan organisasi, memotivasi perilaku pengikut untuk mencapai tujuan, mempengaruhi untuk memperbaiki kelompok dan budayanya. Selain itu juga mempengaruhi interprestasi mengenai peristiwa-peristiwa para pengikutnya, pengorganisasian, dan aktivitas-

\section{5 | B a l a n c a}

Jurnal Ekonomi dan Bisnis Islam

Volume 2 Nomor 1, Januari - Juni 2020 (35 - 43) 
aktivitas untuk mencapai sasaran, memelihara hubungan kerjasama dan kerja kelompok, perolehan dukungan dan kerjasama dari orang-orang diluar kelompok atau organisasi. Sehingga kepemimpinan merupakan sebuah faktor yang sangat penting untuk mempengaruhi dan memberikan arahan kepada para karyawan, apalagi saat ini sistemnya sudah beranjak serba terbuka maka sosok kepemimpinan yang menguatkan para karyawannya. Disisi lain kepemimpinan yang dapat menumbuhkan motivasi kerja para karyawan merupakan kepemimpinan yang dapat menumbuhkan rasa percaya diri yang tinggi dalam melaksanakan semua yang menjadi tugasnya dalam bekerja.

Gaya kepemimpinan yang selama ini diteorikan lebih mengarah bagaimana para pemimpin mampu mempengaruhi para pengikut agar depan sukarela mau melakukan berbagai tindakan bersama yang di perintahkan oleh pemimpin oleh pemimpin tanpa merasa bahwa dirinya di tekan dalam rangka mencapai tujuan organisasi.

Faktor lain yang mempengaruhi hasil kerja selain kepemimpinan yaitu dibutuhkannya motivasi, motivasi sendiri memiliki arti bahwa suatu dorongan kehendak yang menyebabkan seseorang melakukan suatu perbuatan untuk mencapai tujuan tertentu. Motivasi berasal dari kata motif yang berarti "dorongan" atau "rangsangan" atau "daya penggerak" yang ada dalam diri seseorang.

Motivasi kerja adalah suatu keinginan dan dorongan di dalam diri pegawai untuk melaksanakan tugas dan tanggung jawabnya dengan baik. Motivasi timbul dimulai dari adanya kebutuhan dan keinginan. Kedua hal tersebut mempengaruhi perilaku sehingga timbul dorongan-dorongan, selanjutnya dorongan akan membentuk perilaku sehingga tercapai tujuan. Maka dari itu, gaya kepemimpinan dan motivasi merupakan hal yang penting dalam sebuah era modern dimana organsasi menghendaki adanya demokratis dalam pelaksanaan kerja dan motivasi kerja yang baik. Akibat yang mungkin timbul dari adanya gaya kepemimpinan dan motivasi yang buruk adalah penurunan kinerja pegawai yang akan membawa dampak pada penurunan kinerja total perusahaan.

\section{Landasan Teori}

\section{Manajemen Sumber Daya Manusia}

Manajemen sumber daya manusia adalah suatu proses perencanaan, pengoranisasian, pengendalian sumber daya manusia dalam rangka pencapaian tujuan organisasi ${ }^{1}$. Fungsifungsi manajemen sumber daya manusia terdiri dari perencanaan, pengorganisasian, pengarahan, pengendalian, pengadaan, pengembangan kompensasi, pengintergrasian, pemeliharaan, kedisiplinan, dan pemberhentian. Tujuan dari fungsi-fungsi MSDM tersebut adalah perusahaan agar bisa mendapatkan tingkat laba yang tinggi dari pada bunga bank.Sedangkan karyawan agar bisa mendapatkan kepuasan dalam pekerjaan. Dan masyarakat bisa memperoleh barang dan jasa dengan tingkat harga yang sewajarnya serta selalu tersedia di pasar. ${ }^{2}$

\section{Komponen Manajemen Sumber Daya Manusia}

Tenaga kerja manusia dasarnya dibedakan atas pengusaha, karyawan dan pemimpin sebagai berikut.

a) Pengusaha. Pengusaha adalah setiap orang yang menginvestasikan modalnya untuk memperoleh pendapatan dan besarnya pendapatan itu tidak menentu tergantung pada laba yang tersebut.

b) Karyawan. Karyawan merupakan kekayaan utama suatu perusahaan, karena tanpa keikutsertaan mereka aktifitas perusahaan tak akan terjadi. Karyawan adalah penjual jasa (pikiran dan tenagannya) dan mendapat kompensasi

${ }^{1}$ Achmad Slamet, Manajemen Sumber Daya Manusia (Semarang: Unnes Press, 2012). Hlm. 26.

${ }^{2}$ Malayu Hasibuan SP, Organisasi dan Motivasi, Dasar Peningkatan Produktivitas, Jakarta Bumi Aksara. 2011). Hlm. 10.

\section{6 | B a l a n c a}


yang besarnya telah ditetapkan terlebih dahulu.

c) Pemimpin atau Manajer. Pemimpin adalah seseorang yang mempergunakan wewenang dan kepemimpinannya untuk mengarahkan orang lain serta bertanggung jawab atas pekerjaan orang tersebut dalam mencapai suatu tujuan.

\section{Peranan Manajemen Sumber Daya Manusia}

Manajemen sumber daya manusia mengatur dan menetapkan program kepegawaian yang mencakup masalahmasalah sebagai berikut: ${ }^{3}$

a) Menetapkan jumlah, kualtas dan penempatan tenaga kerja yang efektif sesuai dengan kebutuhan perusahaan berdasarkan job description, job specification, job rekruitment, dan job evaluation.

b) Menetapkan penarkan, seleksi, dan penempatan karyawan berdasarkan asas the rigth man in the right place and the right man in the righ job.

c) Menetapkan progam kesejahteraan, pengembangan, promosi dan pemberhentian.

d) Meramalkan penawaran dan permintaan sumber daya manusia pada masa yan akan datang.

e) Memperkirakan keadaan perekonomian pada umumnya dan perkembangan perusahaan pada khususnya.

\section{Kinerja}

Kinerja adalah hasil kerja yang telah dicapai seseorang dari tingkah laku kerjanya dalam melaksanakan aktivitas kerja ${ }^{4}$. Kinerja adalah tingkat kerja individu (pegawai) setelah berusaha atau bekerja keras atau hasil akhir

${ }^{3}$ Malayu Hasibuan SP, Organisasi dan Motivasi, Dasar Peningkatan Produktivitas, Jakarta Bumi Aksara. 2011). Hlm 13

4Sutrisno, Manajemen Keuangan Teori, Konsep Dan Aplikasi, (Yogyakarta: Ekonisia, 2012). Hlm. 151

\section{7| B a l a n c a}

Jurnal Ekonomi dan Bisnis Islam

Volume 2 Nomor 1, Januari - Juni 2020 (35 - 43) dari aktivitas ${ }^{5}$ Kinerja diharapkan menghasilkan mutu pekerjaan yang baik serta jumlah pekerjaan yang sesuai dengan standar. Tingkat pendidikan karyawan sangatlah mempengaruhi kinerjanya, karena dengan pendidikan orang lebih mempunyai wawasan yang lebih luas dan umumnya tingkat pergaulannya juga lebih luas. Selain itu kemampuan seseorang untuk berinisiatif dan berinovasi sangat berpengaruh terhadap kinerjanya ${ }^{6}$.

Untuk mengetahui kinerja karyawan, maka perlu dilakukan proses penilaian kinerja. Pnilaian kinerja sebagai proses mengevaluasi seberapa baik karyawan melakukan perkerjaan mereka jika dibandingkan dengan seperangkat standar dan kemudian mengkomunikasikan informasi tersebut kepada karyawan ${ }^{7}$.

\section{Penilaian Kinerja}

Penilaian kinerja adalah alat yang berguna untuk tidak hanya untuk mengevaluasi kinerja dari para karyawan tetapi juga untuk mengembangkan dan memotivasi kalangan karyawan. Teknik paling tua yang digunakan oleh manajemen untuk meningkatkan kinerja adalah penilaian (appraisal) .Motivasi karyawan untuk bekerja, mengembangkan kemampuan pribadi, dan meningkatkan kemampuan dimasa mendatang dipengaruhi oleh umpan balik mengenai kinerja masa lalu dan pengembangan. Penilaian kinerja (performappraisal) adalah proses dengannya organisasi mengevaluasi pelaksanaan kerja individu serta ada beberapa faktor yang mempengaruhi penilaian kinerja antara lain.

5Ulber Silalahi, Asas-Asas Manajemen. Cetakan Kedua. (PT. Refika Aditama. Bandung, 2013). Hlm. 408.

${ }^{6}$ Henry Simamora, Manajemen Sumber Daya Manusia (Surabaya: Smmas, 2012). Hlm. 338.

${ }^{7}$ Robhert Mathis, Robhert.L dan John Jack, Manajemen Sumber Daya Manusia. Jakarta: Salemba Empat, 2013). Hlm. 382. 
Karakteristik situasi, Deskripsi pekerjaan, spesifikasi pekerja dan standar kinerja pekerjaan, dan tujuan-tujuan penilaian kinerja $^{8}$. Overlapping pekerjaan membuat pelaksana merasa dirugikan dan saling menuduh dan menyudutkan terjadi dalam situasi kerja karena deskripsi pekerjaan ${ }^{9}$.

Sikap para karyawan dan manajer terhadap evaluasi terdapat enam kriteria hasil kinerja yang dapat digunakan yaitu $:^{10}$

1) Kualitas, tingkat dimana hasil aktivitas yang dilakukan mendekati sempurna.

2) Kuantitas, jumlah yang dihasilkan dan dinyatakan dalam istilah.

3) Ketepatan waktu, tingkat suatu aktivitas diselesaikan pada awal yang diinginkan.

\section{Faktor-Faktor yang Mempengaruhi Kinerja} Karyawan

Kinerja merupakan suatu konstruk multidimensional yang mencakup banyak faktor yang mempengaruhinya. Faktor-faktor yang mempengaruhi kinerja adalah ${ }^{11}$ :

a) Faktor Personal/Individu, meliputi pengetahuan, keterampilan, kemampuan, kepercayaan diri, motivasi, dan komitmen yang dimiliki oleh setiap individu.

b) Faktor Kepemimpinan, meliputi; kualitas dalam memberikan dorongan, semangat arahan, dan dukungan yang memberikan manajer dan team leader.

c) Faktor Tim, meliputi; kualitas dukungan dan semangat yang diberikan oleh rekan dalam satu tim, kepercayaan

8 Henry Simamora, Manajemen Sumber Daya Manusia (Surabaya: Smmas, 2012). Hlm. 417

9 Yana Firana dan Ahmad Abbas, Dimensi Keadilan dalam Partisipasi Penyusunan Anggaran dan Kinerja Manajerial Rumah Sakit. (Jesya : Jurnal Ekonomi \&o Syariah, 2020) 99-110.

10 Viethzal Rivai dan Sagala Ela Jauvani, Manajemen sumber daya manusia untuk Perusabaan Dari Teori Ke Praktis. Jakarta: Raja Gravindo, 2013. Hlm. 557.

${ }^{11}$ Mahmudi. Manajemen Sumber Daya Manusia. (Jakarta: Rineka Cipta, 2012) Hlm 21. terhadap sesama anggota tim, kekompakan dan keeratan anggota tim.

d) Faktor Sistem, meliputi; sistem kerja, fasilitas kerja atau infrastruktur yang diberikan oleh organisasi, proses organisasi, dan kultur kinerja dalam organisasi.

e) Faktor Kontekstual (situasional) meliputi; tekanan dan perubahan lingkungan eksternal dan internal.

Pada sistem penilaian kinerja tradisional, kinerja hanya dikaitkan dengan faktor personal, namun dalam kenyataannya kinerja sering diakibatkan oleh faktor-faktor lain diluar faktor personal, seperti sistem, situasi, kepemimpinan, atau tim.

\section{Gaya kepemimpinan}

Gaya kepemimpinan adalah cara yang digunakan memimpin dan memengaruhi para pengikutnya. Gaya kepemimpinan merupakan suatu pola perilaku seorang pemimpin yang khas pada saat memengaruhi anak buah ${ }^{12}$. Dengan kata lain, cara pemimpin bertindak dalam memengaruhi anggota kelompok membentuk gaya kepemimpinan.

Gaya kepemimpinan yang selama ini diteorikan lebih mengarah bagaimana para pemimpin mampu mempengaruhi para pengikut agar depan sukarela mau melakukan berbagai tindakan bersama yang di perintahkan oleh pemimpin oleh pemimpin tanpa merasa bahwa dirinya di tekan dalam rangka mencapai tujuan organisasi.

Gaya kepemimpinan adalah cara pemimpin berprilaku secara konsisten terhadap bawahan sebagai anggota kelompok.

Gaya artinya sikap, gerakan, tingkah laku, sikap yang elok, gerak gerik yang bagus, kekuatan, kesanggupan untuk berbuat baik. Sedangkan gaya kepemimpinan adalah sekumpulan ciri yang digunakan pemimpin untuk mempengaruhi bawahan untuk sasaran organisasi tercapai atau dapat pula dikatakan

\footnotetext{
${ }^{12}$ E.Mulyasa. Praktik Penelitian Tindakan. Bandung:
} Rosdakarya, 2012). Hlm 108. 
bahwa gaya kepemimpinan adalah pola prilaku dan strategi yang disukai dan sering diterapkan oleh seorang pemimpin. ${ }^{13}$

Seorang pemimpin perlu memikirkan gaya kepemimpinan yang paling tepat yakni yang dapat memaksimalkan kinerja dan mudah dalam menyesuaikan dengan segala keadaan dan kondisi dalam organisasi. Kepemimpinan merupakan proses mempengaruhi dalam menentukan tujuan organisasi, memotivasi perilaku pengikut untuk mencapai tujuan, mempengaruhi untuk memperbaiki kelompok dan budayanya. Selain itu juga mempengaruhi interprestasi mengenai pristiwa-pristiwa para pengikutnya, pengorganisasian, dan aktivitas-aktivitas untuk mencapai sasaran, memelihara hubungan kerjasama dan kerja kelompok, perolehan dukungan dan kerjasama dari orang-orang diluar kelompok ${ }^{14}$.

\section{Teori-teori Kepemimpinan}

Beberapa teori kepemimpinan, yaitu ${ }^{15}$.

1. Teori Sifat, Teori ini memandang kepemimpinan sebagai suatu kombinasi sifat-sifat yang tampak dari pimpinan. Asumsi dasar dari teori ini adalah keberhasilan pemimpin di sebabkan karena sifat atau karakteristik, dan kemampuan yang luar biasa yang dimiliki seorang pemimpin, dan oleh sebab itu seseorang dirasa layak untuk memimpin. Adapun sifat karakteristik, dan kemampuan yang luar biasa yang dimiliki seorang pemimpin, antara lain:

${ }^{13}$ Veithzal Rivai dan Sagala Ela Jauvani. Manajemen sumber daya manusia untuk. Perusahaan Dari Teori Ke Praktis. Jakarta: Raja Gravindo, 2013) Hlm 42.

${ }^{14}$ Veithzal Rivai dan Sagala Ela Jauvani. Manajemen sumber daya manusia untuk. Perusahaan Dari Teori Ke Praktis. Jakarta: Raja Gravindo, 2013) Hlm 2.

15 Mulyadi dan Rivai. Manajemen Sumber Daya Manusia. (Jakarta: Letakan Kesembilan, 2012) Hlm. 7
2. Inteligensia. Seorang pemimpin memiliki kecerdesan diatas para bawahannya. Pemimpin dengan kecerdasannya itulah dapat mengatasi masalah yang timbul dalam organisasi, dengan cepat mengetahui permasalahan apa yang timbul dalam organisasi, menganalisis setiap permasalahan, dan dapat memberikan solusi yang efektif, serta dapat diterima semua pihak.

3. Kepribadian. Seorang pemimpin memiliki kepribadian yang menonjol yang dapat dilihat dan dirasakan bawahannya, seperti:

a. Memiliki sifat percaya diri, dan rasa ingin tau yang besar.

b. Memiliki daya ingat yang kuat.

c. Sederhana, dan dapat berkomunikasi dengan baik kepada semua pihak.

d. Mau mendengarkan masukan (ide), dan kritikan dari bawahan.

e. Peka terhadap perubahan globalisasi, baik itu perubahan lingkungan, teknologi, dan prosedur kerja.

f. Mampu beradaptasi dengan perubahanperubahan yang timbul.

g. Berani dan tegas dalam melaksankan tugas pokoknya, dan dalam mengambil sikap, serta mengambil keputusan bagi kepentingan organisasi dan pegawainya.

h. Mampu menyatukan perbedaanperbedaan yang ada dalam organisasi.

4. Karakteristik fisik. Seorang pemimpin dikatakan layak menjadi pemimpin dengan melihat karakteristik fisiknya, yaitu: usia, tinggi badan, berat badan dan penampilan.

a. Teori perilaku, Dalam teori ini perilaku pemimpin merupakan sesuatu yang bisa di pelajari. Jadi seseorang yang dilatih dengan kepemimpinan yang tepat akan meraih keefektifan dalam memimpin. Teori ini memusatkan perhatiannya pada dua aspek perilaku kepemimpinan, yaitu: fungsi kepemimpinan, dan gaya kepemimpinan. Terdapat dua fungsi kepemimpinan, yaitu: a. Fungsi yang berorientasi tugas. b. Fungsi yang 
berorientasi orang atau pemeliharaan kelompok (sosial).

b. Teori situasional, Merupakan suatu pendekatan terhadap kepemimpinan yang menyatakan bahwa pemimpin memahami perilakunya, sifat-sifat bawahannya, dan situasi sebelum menggunakan suatu gaya kepemimpinan tertentu. Pendekatan ataupun teori ini mensyaratkan pemimpin untuk memiliki keterampilan diagnostic dalam perilaku manusia.

\section{Motivasi Kerja}

Motivasi kerja adalah sesuatu yang menimbulkan semangat atau dorongan, dimana kuat lemahnya motivasi tersebut ikut menentukan tinggi rendahnya prestasi kinerjanya ${ }^{16}$. Motivasi kerja merupakan kekuatan yang penting yang harus ada dalam diri pemimpin sehingga ia memiliki keinginan atau semangat yang kuat untuk berusaha dan berkerja keras sehingga dapat diperoleh keberhasilan bagi dirinya dan perusahaan.

Motivasi kerja merupakan suatu faktor yang turut menentukan kinerja seseorang. Motivasi kerja merupakan dorongan dari dalam diri seseorang yang membuat tergerak melakukan kegiatan produktif hingga menghasilkan sesuatu yang bermanfaat bagi dirinya ataupun orang lain. Adanya motivasi kerja ternyata berpengaruh besar terhadap kesuksesan seseorang. Seseorang tidak akan berhasil meraih kesuksesan tanpa adanya dorongan motivasi yang diikuti dengan tekadnya untuk bekerja keras. Memperoleh hasil yang memuaskan membutuhkan proses dan perjuangan yang cukup panjang.

\section{Tujuan Motivasi}

Di dalam perusahaan motivasi berperang sangat penting dalam meningkatkan kinerja

16 Gary Yukl. Kepemimpinan Dalam Organisasi (Alih Bahasa Yusuf Udaya). (Jakarta: Edisi Bahasa Indonesia Victory Jaya Abadi, 2012).Hlm 83
pegawai.Tujuan dalam memberikan motivasi kerja terhadap pegawai dapat melaksanakan tugasnya secara efektif dan efisien.Dengan demikian berarti juga mampu memelihara dan meningkatkan moral, semangat dan gairah kerja, karena dirasakan sebagai pekerjaan yang menentang. Program dengan cara ini suatu organisasi dapat mendorong berkembangnya motivasi berprestasi dalam suatu perusahaan, yang akan memacu tumbuh dan berkembangnya persaingan sehat antara individu/team kerja dalam suatu perusahaan. Tetapi dalam individu setiap manusia tidak semua pegawai termotivasi lewat lingkungan kerjanya yang biasa di sebut dengan motivasi eksternal, tetapi ada juga pegawai yang termotivasi dari dalam dirinya sendiri (motivasi internal) tanpa ada motivasi khusus yang dia dapatkan dalam lingkungan kerjanya dan motivasi yang diinginkan pegawai sehingga pegawai mau bekerja ikhlas demi tercapainya tujuan perusahaan.

\section{Metode Penelitian}

Rancangan penelitian yang digunakan dalam penelitian ini menggunakan metode survey, dimana penelitian ini mengambil sampel dari satu polulasi dan menggunakan kuesioner sebagai alat pengumpul data. Adapun desain dari metode survei ini adalah deskriptif kuantitatif.

Penelitian kuantitatif dengan format deskriptif bertujuan untuk menjelaskan meringkaskan berbagai kondisi, berbagai situasi, atau berbagai variabel yang timbul di masyarakat yang menjadi objek penelitain itu berdasarkan apa yang terjadi ${ }^{17}$.

Penelitian ini termasuk desain penelitian kuantitatif karena merupakan pengembangan konsep dan pengumpulan data untuk menguji pengaruh antara pengaruh Gaya kepemimpinan dan motivasi dalam meningkatkan kinerja pegawai BANK BTPN

17 Burhan Bungin. Metodologi Penelitian Kuantitatif. EdisiKedua.(Jakarta: Kencana, 2013) Hlm. 44

\section{0| B a l a n c a}


Sungguminasa. Penelitan dan pengumpulan data dalam penelitian ini dilakukan pada pegawai SDM BANK BTPN Sungguminasa Kabupaten Gowa, Sulawesi Selatan.

Populasi dalam penelitian jenisnya merupakan populasi yang terbatas dan menurut sifatnya merupakan populasi yang homogen dan populasi dalam penelitian ini adalah karyawan BANK BTPN Cab. Sungguminasa yang berjumlah sebanyak 32 orang. Adapun sampel dalam penelitian ini adalah karyawan BANK BTPN Cab. Sungguminasa yang berjumlah 32 orang.

Teknik pengumpulan data yang digunakan yaitu metode survei kuesioner. Kuesioner atau daftar pertanyaan merupakan teknik pengumpulan data yang dilakukan dengan cara menyusun pertanyaanpertanyaan yang sifatnya tertutup dan terbuka dengan jawaban yang telah disediakan, dan harus diisi oleh responden dengan memilih salah satu alternatif jawaban yang tersedia beserta alasannya.

Teknik analisis yang digunakan dalam penelitian ini adalah analisis kuantitatif merupakan metode analisis dengan angkaangka yang dapat dihitung maupun diukur. Analisis kuantitatif ini dimaksudkan untuk memperkirakan besarnya pengaruh secara kuantitatif dari perubahan satu atau beberapa kejadian lainnya dengan menggunakan alat analisis statistik. Pada penelitian ini, data akan diolah menggunakan software komputer yaitu SPSS (statistical package for social science). Adapun alat analisis yang digunakan yaitu uji validalitas dan reliabilitas..

\section{Hasil Penelitian}

Berdasarkan hasil uji regresi linear berganda, maka dapat dihasilkan penelitian sebagai berikut.

\section{Pengaruh gaya kepemimpinan terhadap kinerja pegawai}

Berdasarkan uji dari tabel koefisien uji statistik $t$, nilai $t$ hitung untuk variabel gaya kepemimpinan adalah sebesar 3.233 sedangkan $\mathrm{t}$ tabel 1,695. Maka dapat diketahui $\mathrm{t}$ hitung $>\mathrm{t}$ tabel. dan nilai signifikan 0,002 lebih kecil dari 0,05. Sehingga dapat disimpulkan bahwa gaya kepemimpinan berpengaruh secara signifikan terhadap kinerja pegawai.

Hasil penelitian ini sama dengan penelitian yang dilakukan oleh Penelitian yang dilakukan Bryanjohannes dalam penelitiannya yang berjudul "pengaruh gaya kepemimpinan dan motivasi terrhadap kinerja karyawan pada PT. Bank Negara Indonesia, Tbk" menghasilkan bahwa adanya hubungan langsung yang signifikan positif antara gaya kepemimpinan dengan kinerja pegawai. Dapat diartikan bahwa gaya kepemimpinan berpengaruh signifikan terhadap kinerja pegawai ${ }^{18}$.

Senada dengan pendapat yang dijelaskan bahwa, gaya kepemimpinan adalah cara yang digunakan memimpin dan memengaruhi para pengikutnya. Gaya kepemimpinan merupakan suatu pola perilaku seorang pemimpin yang khas pada saat memengaruhi anak buah. Dengan kata lain, cara pemimpin bertindak dalam memengaruhi anggota kelompok membentuk gaya kepemimpinan ${ }^{19}$.

\section{Pengaruh motivasi terhadap kinerja pegawai}

Berdasarkan dari tabel koefisien uji statistik $t$, nilai $t$ hitung untuk variabel motivasi adalah sebesar 5,637 sedangkan $\mathrm{t}$ tabel 1,695. Maka dapat diketahui $\mathrm{t}$ hitung $>\mathrm{t}$ tabel, dan nilai signifikan0,000 lebih kecil dari 0,05 . Sehingga dapat disimpulkan bahwa motivasi berpengaruh secara signifikan terhadap kinerja pegawai Bank BTPN Cab. Sungguminasa Kab. Gowa.

Teori yang dijelaskan bahwa motivasi kerja merupakan suatu faktor yang turut menentukan kinerja seseorang. Motivasi kerja

18Bryanjohannes. Pengaruh Gaya Kepemimpinan Dan Motivasi Terrhadap Kinerja Karyawan Pada Pt. Bank Negara Indonesia, Tbk. (Https://Ejournal.Unsrat.Ac.Id), 2014.

19 E.Mulyasa. Praktik Penelitian Tindakan. (Bandung: Rosdakarya, 2012). Hlm 108.

\section{B a l a n c a}


merupakan dorongan dari dalam diri seseorang yang membuat tergerak melakukan kegiatan produktif hingga menghasilkan sesuatu yang bermanfaat bagi dirinya ataupun orang lain. Adanya motivasi kerja ternyata berpengaruh besar terhadap kesuksesan seseorang.

Seseorang tidak akan berhasil meraih kesuksesan tanpa adanya dorongan motivasi yang diikuti dengan tekad kyat untuk bekerja keras. Memperoleh hasil yang memuaskan membutuhkan proses dan perjuangan yang cukup panjang.

\section{Kesimpulan}

Berdasarkan hasil penelitian yang dilakukan di Bank BTPN Cabang Sungguminasa Kabupaten Gowa, maka akan di berikan beberapa kesimpulan sebagai berikut :

1) Variabel Gaya Kepemimpinan berpengaruh positif $(3,233)$ dan signifikan $(0,002)$ terhadap kinerja.

2) Variable motivasi berpengaruh positif $(5,637)$ dan signifikan $(0,000)$ terhadap kinerja.

Berdasarkan hasil penelitian maka penulis sarankan kirannya PT. Bank BTPN Cabang Sungguminasa Kabupaten Gowa sebagai berikut:

1) Hendaknya pimpinan PT. Bank BTPN Cabang sungguminasa Kabupaten Gowa terus memberikan kesempatan kepada karyawan untuk menyampaikan ide, saran dan kritiknya, serta mendukung karyawan dalam mencari solusi dalam menyelesaikan pekerjaanya.

2) Kiranya motivasi kerja terus diberikan kepada karyawan seperti gaji, pemberian penghargaan, perhatian, serta menjalin komunikasi yang baik antar karyawan agar sumber daya yang ada juga terus meningkat demi terwujudnya tujuan organisasi.

3) Kepada peneliti selanjutnya yang berminat melakukan penelitian tentang gaya kepemimpinan dan motivasi sebaiknya pelajari dan kenali terlebih dahulu tentang gaya kepemimpinan dan motivasi karena hal ini sangat berkaitan dengan kinerja karyawan.

\section{Daftar Pustaka}

Bryanjohannes. Pengaruh Gaya Kepemimpinan Dan Motivasi Terrhadap Kinerja Karyawan Pada Pt. Bank Negara Indonesia, Tbk. (Https://Ejournal.Unsrat.Ac.Id), 2014.

Bungin, Burhan. Metodologi Penelitian Kuantitatif. EdisiKedua. Jakarta: Kencana, 2013.

Firana, Y., \& Abbas, A. "Dimensi Keadilan dalam Partisipasi Penyusunan Anggaran dan Kinerja Manajerial Rumah Sakit". Jesya (Jurnal Ekonomi \& Syariah), Vol 3 No. 2, (2020): 99-110. https://doi.org/10.36778/jesya.v3i2.150.

Gary Yukl. Kepemimpinan Dalam Organisasi (Alih Bahasa Yusuf Udaya). Jakarta: Edisi Bahasa Indonesia Victory Jaya Abadi, 2012.

Ghozali, Imam. Aplikasi Analisis Multivariate Dengan Program Spss, Semarang Badan Penerbit Universitas Di Ponegoro, 2013.

Hamzah B. Uno, M. Teori Motivasi dan Pengukurannya. Jakarta: Bumi Aksara, 2012.

Hasibuan, Malayu SP. Organisasi dan Motivasi, Dasar Peningkatan Produktivitas. Jakarta Bumi Aksara, 2013.

Larasati. Pengaruh Motivasi Kerja Terhadap Kinerja Karyawan Wilayah Telkom Jabar Barat Utara (Witel Bekasi), 2014

Olivia Theodora. Pengaruh Motivasi Kerja Terhadap Kinerja Karyawan PT .Sejahtera Motor Gemilang, 2015.

Mahmudi. Manajemen Sumber Daya Manusia. Jakarta: Rineka Cipta, 2012

Mathis, Robhert.L Dan Jack, John. Manajemen Sumber Daya Manusia. Salemba Empat, Jakarta, 2013

Mulyadi \& Rivai. Manajemen Sumber Daya Manusia. Jakarta: Letakan Kesembilan, 2012.

Mulyasa. E. Praktik Penelitian Tindakan. Bandung: Rosdakarya, 2012.

Rivai, Veithzal dan Sagala Ela Jauvani. Manajemen sumber daya manusia untuk Perusahaan Dari Teori Ke Praktis. Jakarta: Raja Gravindo, 2013.

Rivai, Veithzal M.B.A. Manajemen Sumber Daya Manusia Untuk Perusahaan. Jakarta: Raja Grafindo, 2013.

\section{2 $\quad$ B a l a n c a}


Saputra Andri. Pengaruh Gaya Kepemimpinan dan Motivasi Kerja Terhadap Kinerja Karyawan Badan Statistik BPS Kota Padang. Journal Of Economic And Economic Education $\quad$ Vol.2 $\quad$ No.2 (Https://Media.Neliti.Com/Media/Pu blications/43020-ID), 2014.

Silalahi, Ulber. Asas-Asas Manajemen. Cetakan Kedua. PT. Refika Aditama. Bandung, 2013.

Simamora, Henry. Manajemen Sumber Daya Manusia. Surabaya: Smmas, 2012

Slamet, Achmad. 2012. Manajemen Sumber Daya Manusia. Semarang: Unnes Press.

Sutrisno. Manajemen Keuangan Teori, Konsep Dan Aplikasi. Yogyakarta: Ekonisia, 2012 